\title{
Analysis of Selling Price Determination Using Cost Plus Pricing Method in Three Saudara Chicken Livestock Business, Selatan Bengkulu Regency
}

\section{Analisis Penetapan Harga Jual dengan Metode Cost Plus Pricing pada Usaha Ternak Ayam Potong Tiga Saudara Kabupaten Bengkulu Selatan}

\author{
Rera Marsela 1); Sulisti Afriani 2); Yun Fitriano ${ }^{2)}$ \\ 1) Study Program of Accounting Faculty of Econimic, Universitas Dehasen Bengkulu \\ 2) Department of Accounting, Faculty of Economic, Universitas Dehasen Bengkulu \\ Email: ${ }^{1)}$ reramarsela0599@gmail.com; ${ }^{2)}$ sulistiafriani@unived.ac.id; ${ }^{2)}$ Yunfitriano@unived.ac.id
}

How to Cite:

Marsela, R., Afriani, S., Fitriano, Y. (2022). Analysis of Selling Price Determination Using Cost Plus Pricing Method in Three Saudara Chicken Livestock Business, Selatan Bengkulu Regency. Jurnal Ekonomi Manajemen Akuntansi Dan Keuangan, 3(1). DOI: https://doi.org/10.53697/emak.v3i1

ARTICLE HISTORY

Received [22 Desember 2021]

Revised [30 Desember 2021]

Accepted [10 Januari 2022]

\section{KEYWORDS}

Selling Price Determination,

Cost Plus Pricing

This is an open access article under the $C C-B Y$-SA license

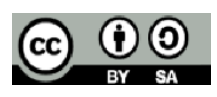

\section{ABSTRAK}

Tujuan penelitian adalah untuk mengetahui dan meganalisis penetapan harga jual dengan Metode Cost Plus Pricing pada Usaha Ternak Ayam Potong Tiga Saudara Kabupaten Bengkulu Selatan. Metode analisis yang digunakan dalam penelitian ini adalah metode deskriptif komparatif. Berdasarkan perhitungan harga pokok produksi yang dilakukan oleh Usaha Ternak Ayam Potong Tiga Saudara Kabupaten Bengkulu Selatan harga pokok produksi ayam potong perekor adalah sebesar Rp. 32.238.-. dan penetapan harga jual berdasarkan harga pasaran yaitu sebesar Rp. 38.000 perekor sehingga laba yang diperoleh sebesar Rp. 5.872 perekor. Berdasarkan metode cost plus pricing dengan pendekatan full costing diperoleh harga pokok produksi ayam potong perekor sebesar Rp. 33.418 ,-. Dengan penetapan keuntungan sebesar 20\% dari harga pokok produksi maka jumlah harga jual ayam potong perekor sebesar Rp. 40.000,- sehingga laba yang diperoleh sebesar Rp. 6,582,- perekor. Terdapat selisih perhitungan harga pokok produksi antara perhitungan perusahaan dengan metode cost plus pricing karena pada perhitungan perusahaan tidak memasukan biaya tenaga kerja dan biaya overhead pabrik.

\section{ABSTRACT}

The purpose of the study was to determine and analyze the determination of the selling price using the Cost Plus Pricing Method in the Three Brothers Chicken Livestock Business, South Bengkulu Regency. The analytical method used in this study is a comparative descriptive method. Based on the calculation of the cost of production carried out by the Three Brothers Chicken Livestock Business, South Bengkulu Regency, the cost of production of broiler chickens per head is Rp. 32,238.-. and the determination of the selling price based on the market price of Rp. 38,000 per head so that the profit earned is Rp. 5,872 fish. Based on the cost plus pricing method with a full costing approach, the cost of production of broiler chickens is Rp. 33,418,-. With the determination of a profit of $20 \%$ of the cost of production, the total selling price of chicken per head is $R p .40,000$, - so that the profit earned is Rp. 6,582,- per head. There is a difference in the calculation of the cost of production between the company's calculation and the cost plus pricing method because the company's calculation does not include labor costs and 


\section{PENDAHULUAN}

Ayam broiler memiliki kelebihan dibanding dengan ayam lain, yaitu pertumbuhan yang sangat cepat dengan bobot tubuh yang tinggi dan dalam waktu yang relatif singkat, konversi pakan kecil, siap dipotong diusia muda dan menghasilkan daging berserat yang berkualitas. Pesatnya perkembangan ayam broiler merupakan upaya penanganan untuk mengimbangi kebutuhan masyarakat terhadap daging ayam (Nurjannah, 2017:5)

Harga jual suatu produk merupakan salah satu unsur yang menjadi pertimbangan konsumen dalam memutuskan untuk membeli produk tersebut. Apabila harga yang ditawarkan tidak sesuai dengan kualitas barang yang dijual maka konsumen bisa beralih ke produk lain. Dari persoalan tersebut di atas, maka perusahaan harus menetapkan harga jual yang sesuai dengan kualitas produk, kondisi pasar, biaya yang dikeluarkan, dan laba yang diinginkan.

Harga jual produk selain mempengaruhi volume penjualan juga akan mempengaruhi jumlah pendapatan perusahaan. Salah satu persoalan rumit yang dihadapi oleh manajemen perusahaan adalah menetapkan harga jual produk perusahaan. Harga jual produk perusahaan sangat berpengaruh terhadap keberhasilan perusahaan dalam mencapai tujuan. Harga jual yang terlalu tinggi akan membuat konsumen tidak membeli atau mengurangi jumlah pembelian produk perusahaan sehingga perusahaan tidak akan memperoleh pendapatan dan laba yang cukup. Sebaliknya harga jual yang terlalu rendah akan membuat perusahan tidak mampu mencapai laba usaha yang direncanakan. Karena itu, menetapkan harga jual produk perusahaan pada harga yang tepat sangat penting bagi perusahaan agar tujuan perusahaan secara umum dapat tercapai.

Penentuan harga jual produk memerlukan berbagai pertimbangan yang terintegrasi mulai dari biaya produksi, biaya operasional, target laba yang diinginkan perusahaan, daya beli konsumen, harga jual pesaing, kondisi perekonomian secara umum, elastisitas harga produk dsb. Walaupun terdapat banyak aspek yang dipertimbangkan oleh perusahaan dalam menentukan harga jual produk, tetapi seringkali faktor biaya dijadikan titik tolak dalam penetapan harga jual produk. Kebijakan harga jual produk dan biaya akan selalu berubahubah sejalan dengan perubahan biaya produk dan kondisi pasar. Biaya yang dikeluarkan perusahaan untuk menghasilkan sejumlah produk di dalam suatu periode akan dijadikan dasar untuk menetapkan harga jual produk.

Dalam penetapan harga pokok dapat menggunakan metode cost plus pricing. Cost plus pricing method yaitu metode penentuan harga jual produk dimana harga dihitung berdasarkan biaya produksi dan biaya penjualan serta tambahan mark up yang pantas (Fitrah dan Endang, 2014:99). Metode cost plus pricing merupakan metode penentuan harga melalui pendekatan biaya yang didasarkan atas biaya produksi maupun biaya non produksi yang tidak lepas dari penentuan harga pokok produksi. Untuk usaha peternakan khususnya peternakan ayam potong metode cost plus prcing dapat digunakan sebagai metode penetapan harga jual, karena dengan metode ini setelah dilakukan perhitungan harga pokok produksi selanjutnya menambahkan dengan besarnya keuangan atau laba yang diharapkan.

Usaha Ternak Ayam Potong Tiga Saudara Kabupaten Bengkulu Selatan adalah sebuah perusahaan perseorangan yang bergerak di bidang peternakan ayam potong. Selama ini Usaha Ternak Ayam Potong Tiga Saudara Kabupaten Bengkulu Selatan dalam menentukan harga jualnya masih berdasarkan harga pasar dan belum ada ketetapan dalam penentuan harga jual. Karena belum adanya metode yang digunakan oleh Usaha Ternak Ayam Potong Tiga Saudara Kabupaten Bengkulu Selatan dalam penentuan harga jual terkadang dapat 
mengakibatkan kerugian bagi perusahaan dikarenakan terjadinya kenaikan bahan baku. Jika Usaha Ternak Ayam Potong Tiga Saudara Kabupaten Bengkulu Selatan menggunakan metode yang tepat dalam penetapan harga jual maka akan memperkecil terjadinya kerugian.

\section{LANDASAN TEORI}

\section{Harga Pokok Produksi}

Hansen dan Mowen (2014:162) menjelaskan pengertian harga pokok produksi adalah “harga pokok produksi adalah biaya dari bahan baku langsung dan biaya tenaga kerja langsung pada produk dengan penelusuran langsung dengan dibebankan biaya overhead pabrik dengan menggunakan penelusuran penggerak dan alokasi". Pengertian yang lain dikemukakan oleh Mulyadi (2014:17) berpendapat harga pokok produksi adalah "biaya - biaya yang dikeluarkan dalam pengolahan bahan baku menjadi sebuah produk".

\section{Harga Jual}

Tujuan akhir suatu perusahaan yaitu utnuk mendapatkan laba yang sebesar-besarnya, yang dapat menutup semua biaya produksi yang telah dikeluarkan dalam melakukan proses produksi suatu perusahaan. Bukan hanya memproduksi saja, tapi perusahaan harus memasarkannya juga. Dengan menetapkan harga jual yang wajar, yang didapat dari semua biaya produksi ditambah dengan persentase laba yang wajar, perusahaan dapat memperoleh laba dan menutup semua biaya produksi yang telah dikeluarkannya. (Mulyadi, 2014:66)

Pengertian harga jual menurut Supriyono (2014:332) adalah sebagai berikut: "Jumlah moneter yang dibebankan untuk satu unit usaha kepada pembeli atau pelanggan untuk barang atau jasa yang dijual atau diserahkan". Sedangkan menurut Mulyadi (2014:78) adalah sebagai berikut: "Harga jual suatu produk terbentuk dipasar sebagai interaksi antara jumlah permintaan dan penawaran dipasar.

\section{Keputusan Penetapan Harga Jual}

Menurut Supriyono, (2014:332), keputusan penentuan harga jual adalah "Penentuan harga jual produk atau jasa suatu organisasi yang umumnya dibuat untuk jangka pendek". Keputusan penetapan harga jual biasanya dibuat berulang-ulang, karena harga jual dipengaruhi oleh perubahan lingkungan eksternal dan intenal perusahaan. Perubahan harga jual bertujuan agar harga jual yang baru dapat mencerminkan biaya saat ini atau malahan mencerminkan biaya masa depan.

\section{METODE PENELITIAN}

Dalam penelitian ini, peneliti akan menentukan penetapan harga jual pada usaha ternak ayam potong tiga saudara di Kabupaten Bengkulu Selatan dengan metode cost plus pricing pendekatan full costing menurut Mulyadi (2017:349), dihitung menggunakan rumus :

Untuk takisran biaya penuh dihitung dengan rumus sebagai berikut:

Biaya bahan baku

Biaya tenaga kerja langsung

Biaya overhead pabrik

Taksiran total biaya produksi

Biaya administrasi dan umum

Biaya pemasaran

Taksiran total biaya komersial

Taksiran biaya penuh
$X X X$

$X X X$
$X X X$

$X X X$

$X X X$

$X X X$

$X X X$

$X X X$ 
Perhitungan harga pokok per unit produksi dengan menggunakan metode kalkulasi bagi yang digunakan untuk menyusun laporan biaya produksi dengan metode full costing, menggunakan rumus perhitungan harga pokok per-unit produksi yang dikemukakan oleh Mulyadi (2017:353), adalah sebagai berikut:

"Harga pokok produksi perunit: " "jumlah semua biaya" /"jumlah unit yang diproduksi"

Besarnya laba yang diharapkan akan disesuaikan dengan keinginan dari usaha ternak ayam potong tiga saudara Bengkulu Selatan dan ditetapkan sebesar $20 \%$.

Adapun tahap-tahap dalam penelitian ini adalah sebagai berikut:

1. Melakukan pengumpulan data yang diperlukan seperti jumlah bahan baku, bahan penolong dan biaya overhead pabrik yang digunakan oleh Usaha Ternak Ayam Potong Tiga Saudara Kabupaten Bengkulu Selatan selama satu kali priode produksi.

2. Setelah data-data dikumpulkan akan dilakukan pengolahan data secara manual dengan cara menghitung total biaya produksi yang dikeluarkan oleh Usaha Ternak Ayam Potong Tiga Saudara Kabupaten Bengkulu Selatan menggunakan taksiran biaya penuh.

3. Selanjutnya akan menghitung harga jual dengan menggunakan rumus cost plus costing.

4. Membuat kesimpulan atas semua penelitian yang dilakukan.

\section{HASIL DAN PEMBAHASAN}

\section{Perhitungan Harga Pokok Produksi Dengan Metode Full Costing}

Berdasarkan perhitungan di atas maka dapat dibuat perhitungan laporan harga pokok produksi pada Usaha Ternak Ayam Potong Tiga Saudara Kabupaten Bengkulu Selatan untuk memproduksi ayam potong selama satu periode berdasarkan teori yang disampaikan oleh Mulyadi dengan metode Full Costing seperti pada tabel 1.

Tabel 1. Total Harga Pokok Produksi Dengan Metode Full Costing

\begin{tabular}{|c|c|}
\hline \multirow{2}{*}{1 Keterangan } & \multirow[t]{2}{*}{ Total Biaya } \\
\hline & \\
\hline a. Biaya bibit & $88,000,000$ \\
\hline b. Biaya pakan & $255,000,000$ \\
\hline 2. Biaya tenaga kerja langsung & $4,000,000$ \\
\hline 3. Biaya overhead pabrik & \\
\hline a. Biaya bahan penolong & $1,739,000$ \\
\hline d. Biaya sekam padi & 320,000 \\
\hline e. Biaya listrik & $6,859,000$ \\
\hline f. Biaya telepon & 120,000 \\
\hline g. Biaya bensin & 650,000 \\
\hline h. Biaya penyusutan peralatan & 732,000 \\
\hline i. Biaya penyusutan kendaraan & 250,000 \\
\hline j. Biaya penyusutan kandang & $1,042,000$ \\
\hline 4. Biaya Non Produksi & \\
\hline Biaya administrasi dan umum & 195,000 \\
\hline Total Harga Pokok Produksi (Rupiah) & $358,907,000$ \\
\hline Total Ayam yang dijual & 10,740 \\
\hline Total Harga Pokok Produksi Per ekor & 33,418 \\
\hline
\end{tabular}

\section{Perhitungan dan Penetapan Harga Pokok Penjualan Menggunakan Metode Cost Plus Pricing}

Untuk penetapan harga pokok penjualan berdasarkan perusahaan (Usaha Ternak Ayam Potong Tiga Saudara Kabupaten Bengkulu Selatan) selama ini penetapan harga jual tidak memiliki patokan atau ketetapan dikarenan Usaha Ternak Ayam Potong Tiga Saudara Kabupaten Bengkulu 
Selatan hanya menetapkan harga jual berdasakan harga pasar saja. Harga jual yang ditetapkan oleh Usaha Ternak Ayam Potong Tiga Saudara Kabupaten Bengkulu Selatan adalah sebesar Rp. 38.000,per ekor.

Dalam penentuan harga jual metode yang digunakan adalah metode cost plus pricing pendekatan full costing menurut Mulyadi (2017:349):

Harga jual = taksiran biaya penuh + laba yang diharapkan

Besarnya laba yang diharapkan akan disesuaikan dengan keinginan dari usaha ternak ayam potong tiga saudara Bengkulu Selatan dan ditetapkan sebesar $20 \%$. Maka dapat dihitung harga jual yang akan diberikan kepada konsumen sebagai berikut:
Harga pokok produksi perekor
:Rp. 33.418,-
Keuntungan $20 \%(20 \% \times 33.418)$
:Rp. 6.683 ,-
Jumlah harga jual
:Rp. 40.102,

Maka berdasarkan perhitungan di atas Usaha Ternak Ayam Potong Tiga Saudara Kabupaten Bengkulu Selatan dapat menjual ayam potong perekor sebesar Rp. 40.102.- dibulatkan menjadi Rp. 40.000,- dan perusahaan telah mendapakan keuntungan sebesar $20 \%$.

\section{Pembahasan}

Berdasarkan hasil penelitian maka dapat diketahui bahwa terdapat perbedaan jumlah harga pokok untuk memproduksi ayam potong untuk satu periode antara perhitungan yang dilakukan oleh Usaha Ternak Ayam Potong Tiga Saudara Kabupaten Bengkulu Selatan dengan perhitungan harga pokok produksi dan peneptan harga jual dengan metode cost plus pricing menurut teori Mulyadi. Adapun perbedaannya dapat dilihat pada tabel berikut ini.

Tabel 2. Perbandingan Perhitungan Penetapan Harga Jual Menurut Usaha Ternak Ayam Potong Tiga Saudara Kabupaten Bengkulu Selatan Dengan Metode Cost Plus Pricing

\begin{tabular}{|l|l|l|l|}
\hline Keterangan & Harga Pokok Perekor & $\begin{array}{l}\text { Harga Jual } \\
\text { Perekor }\end{array}$ & Laba Perekor \\
\hline Metode Perusahaan & 32,128 & 38,000 & 5,872 \\
\hline $\begin{array}{l}\text { Metode Cost Plus } \\
\text { Pricing }\end{array}$ & 33,418 & 40,000 & 6,582 \\
\hline
\end{tabular}

Sumber : Hasil Penelitian dan Diolah, 2021

Berdasarkan tabel di atas dapat dilihat terdapat selisih perhitungan antara perhitungan yang dilakukan oleh Usaha Ternak Ayam Potong Tiga Saudara Kabupaten Bengkulu Selatan dengan perhitungan yang dilakukan penulis dengan metode cost plus pricing. Menurut perhitungan Usaha Ternak Ayam Potong Tiga Saudara Kabupaten Bengkulu Selatan harga pokok produksi perekor ayam potong adalah sebear Rp. 5.872 sedangkan menurut metode cost plus pricing besarnya harga pokok perekor ayam potong sebesar Rp. 6.482,- maka adanya perbedaan perhitungan penetapan harga per ekor menurut perhitungan perusahaan dibandingkan perhitungan menurut metode cost plus pricing.

Perbedaan tersebut disebabkan karena adanya distorasi biaya tenaga kerja langsung yang tidak dihitung oleh Usaha Ternak Ayam Potong Tiga Saudara Kabupaten Bengkulu Selatan, karena biaya tenaga kerja hanya dihitung sebagai biaya operasional. Sementara itu masih banyak lagi biaya produksi yang tidak dibebankan kepada produk seperti biaya listrik. biaya telepon. biaya penyusutan dan biaya non produksi. Hal ini akan mengakibatkan kecilnya keuntungan yang diperoleh oleh perusahaan karena penentuan harga pokok produksi yang terlalu kecil.

Hal ini dikarenakan penghitungan metode Cost Plus Pricing dengan pendekatan full costing lebih rinci dalam memasukkan komponen biaya produksi. Sedangkan penghitungan yang dilakukan perusahaan belum secara menyeluruh memasukkan komponen biaya yang seharusnya diperhitungkan dalam menetapkan harga pokok produksi seperti biaya overhead 
pabrik yang belum semuanya dihitung, sehingga nilai yang dihasilkan lebih rendah dibanding penghitungan harga pokok produksi dengan metode Full Costing.

Dalam penentuan harga jual juga terdapat perbedaan antara perhitungan yang dilakukan oleh Usaha Ternak Ayam Potong Tiga Saudara Kabupaten Bengkulu Selatan dengan perhitungan yang dilakukan oleh penulis. Usaha Ternak Ayam Potong Tiga Saudara Kabupaten Bengkulu Selatan menetapkan harga jual hanya berdasarkan harga pasar saja sedangkan jika menggunakan metode cost plus pricing Usaha Ternak Ayam Potong Tiga Saudara Kabupaten Bengkulu Selatan cukup menambahkan besarnya persentase keuntungan yang diinginkan. Berdasarkan perhitungan diatas dengan menambahkan keuntungan sebesar 20\%. Sedangkan jika berdasarkan perhitungan perusahaan penetapan harga jual berdasarkan harga pasaran yaitu sebesar Rp. 38.000 perekor sehingga laba yang diperoleh sebesar Rp5.872,- perekor. Meskipun laba yang diperoleh cukup tinggi namun perusahaan belum memperhitungan semua biaya yang harus dikeluarkan.

Dengan adanya penentuan penetapan harga jual Usaha Ternak Ayam Potong Tiga Saudara Kabupaten Bengkulu Selatan akan memperoleh keuntungan sesuai dengan yang diharapkan. Dengan metode cost plus pricing maka pendapatan yang diperoleh oleh perusahaan lebih besar sehingga laba bersih yang diperoleh oleh perusahaan juga lebih besar serta laba yang diinginkan oleh perusahaan juga dapat dipenuhi

\section{KESIMPULAN DAN SARAN}

\section{Kesimpulan}

1. Berdasarkan perhitungan harga pokok produksi yang dilakukan oleh Usaha Ternak Ayam Potong Tiga Saudara Kabupaten Bengkulu Selatan harga pokok produksi ayam potong perekor adalah sebesar Rp. 32.238.-. dan penetapan harga jual berdasarkan harga pasaran yaitu sebesar Rp. 38.000 perekor sehingga laba yang diperoleh sebesar Rp. 5.872 perekor.

2. Berdasarkan metode cost plus pricing dengan pendekatan full costing diperoleh harga pokok produksi ayam potong perekor sebesar Rp. 33.418,-. Dengan penetapan keuntungan sebesar $20 \%$ dari harga pokok produksi maka jumlah harga jual ayam potong perekor sebesar Rp. 40.000,- sehingga laba yang diperoleh sebesar Rp. 6,582,- perekor.

3. Terdapat selisih perhitungan harga pokok produksi antara perhitungan perusahaan dengan metode cost plus pricing karena pada perhitungan perusahaan tidak memasukan biaya tenaga kerja dan biaya overhead pabrik.

\section{Saran}

1. Usaha Ternak Ayam Potong Tiga Saudara Kabupaten Bengkulu Selatan disarankan untuk mencatat semua biaya yang terkait dengan proses produksi secara rinci, termasuk memperhitungkan biaya overhead yang digunakan untuk menentukan harga pokok produksi seperti biaya penyusutan sehingga diperoleh perhitungan harga pokok produksi yang sebenarnya. Penentuan harga pokok produksi yang tepat akan membantu perusahaan untuk menetapkan harga jual yang tepat pula.

2. Diharapkan kepada Usaha Ternak Ayam Potong Tiga Saudara Kabupaten Bengkulu Selatan dalam penetapan harga jual menggunakan metode cost plus pricing karena pada metode ini biaya - biaya diidentifikasi dengan lebih akurat daripada metode yang digunakan oleh perusahaan 


\section{DAFTAR PUSTAKA}

Fitrah, Rezanda dan Endang Dwi Retnani. 2014. Penentuan Harga Jual Menggunakan Cost Plus Pricing DenganPendekatan Variable Costing. Jurnal Ilmu dan Riset Akuntansi, Vol.3, No.11

Ghozali. Iman. 2015. Teori Akuntansi. Edisi Revisi. Semarang. Universitas Diponegoro.

Hansen dan Mowen. 2014. Akuntansi Manajerial. Buku 1 edisi 8. Jakarta: Salemba Empat

Ikawati. Abriyana Diya. 2018. Penetapan Harga Jual Dengan Metode Cost Plus Pricing Pada Warung Sederhana 2 Jetis Kulon Surabaya. Jurnal Ekonomi Universitas Negeri Surabaya

Kamarudin. Ahmad, 2017. Akuntansi Biaya. Jakarta:Rajawali Pers

Kondoy, Irvana Marina. 2015. Penerapan Cost Plus Pricing Dalam Keputusan Penetapan Harga Jual Untuk Pesanan Khusus Pada Ud. Dewa Bakery Manado. Jurnal Berkala IImiah Efisiensi Volume 15 No. 03

Kotler, P dan Gary Armstrong. 2017. Prinsip-prinsip Pemasaran. Jakarta : Erlangga.

Machfoedz, Mas'ud. 2017. Akuntansi Manajemen, Perencanaan dan Pembuatan Keputusan Jangka Pendek. Buku 1. Edisi 5. Yogyakata :BPFE.

Monroe, K.B., 2015. Pricing, Making Profitable Decissions, Second Edition, McGraw-Hill, New York.

Moray. Jessica Claudia. 2014. Penetapan Harga Jual Dengan Cost Plus Pricing Menggunakan Pendekatan Full Costing Pada UD Gladys Bakery. Jurnal EMBA Vol.2 No.2 Juni 2014

Mulyadi, 2017, Akuntansi Manajemen, Edisi tiga,Yogyakarta : Salemba Empat

Mulyadi. 2014. Akuntansi Biaya. Edisi 5. Yogyakarta. Unit Penerbit dan Percetakan Sekolah Tinggi IImu Manajemen. YKPN

Nazir. 2014. Metode Penelitian. Bogor. Ghalia Indonesia.

Nurjannah. 2017. Kemilaunya Broiler Riuhnya Kemitraan. Poultry Indonesia. GAPPI. Jakarta.

Priyono. 2014. Performa Pelaksanaan Kemitraan dalam usaha peternakan ayam ras pedaging. Jurnal vol. Diakses 25/03/2011. PT. Bina Aksara. Jakart

Santoso. 2017. Akuntansi Biaya Perencanaan Dan Pengendalian Biaya Serta Pembuatan Keputusan. Yogyakarta. BPFE Universitas Gadjah Mada.

Simamora. Henry. 2016. Akuntansi Basis Pengambilan Keputusan Bisnis. Jilid II. Jakarta:Salemba Empat.

Sugiyono. 2013. Metode Penelitian Kualitatif Kuantitatif dan R\&D. Penerbit Alfabeta. Bandung.

Supriyono. 2014. Akuntansi Biaya Pengumpulan Dan Penentuan Harga Pokok. Yogyakarta. BPFE Universitas Gadjah Mada. 